\title{
Studi Farmakokinetika Kodein pada Kelinci setelah Pemberian Intravena Bolus
}

\author{
(PHARMACOKINETIC CODEINE IN RABITT AFTER BOLUS INTRAVENOUS)
}

I Made Agus Gelgel Wirasuta*, Ni Made Listiari, Dewa Ayu Swastini,

Jurusan Farmasi Fakultas Matematika dan Ilmu Pengetahuan Alam, Universitas Udayana. Kampus Bukit Jimbaran, Kuta Selatan Badung Bali, Indonesia 80361.

*Email: mgelgell@yahoo.de

\begin{abstract}
ABSTRAK
Kodein sering ditemukan dalam heroin ilegal. Pemanfaatan kodein sebagai marker pengguna heroin ilegal diperlukan data farmakokinetik kodein. Sebelas kelinci diinjeksi dengan 11,04 mg kodein melalui vena marginalis. Darah diambil pada menit ke-5, 15, 30, 60, 90, dan 120 setelah pemberian. Serum disimpan pada suhu $-20{ }^{\circ} \mathrm{C}$ sebelum dianalisis. Protein darah diendapkan menggunakan isopropanol. Kodein diekstraksi menggunakan kloroform: isopropanol (3:1) dengan dafar fosfat $0,2 \mathrm{~N}, \mathrm{pH} 9,3$ kemudian dielusi dengan fase gerak toluene-asetone-etanol-amonia (45:45:7:3) dan fase diam plat alamunium silika Gel $60 \mathrm{~F}_{254}$. Kodein ditetapkan dengan spektrofotodensitometri pada $215 \mathrm{~nm}$. Batas deteksi dan kuantisasi kodein adalah 184,43 ng/spot dan 563,62, berturut-turut. Rerataan perolehan kembali ekstraksi adalah $60,60 \%$. Profil konsentrasi kodein menurut pada fase awal dan kembali meningkat pada pase akhir, hal ini menandakan telah terjadi siklus enterohepatis. Kodein mengikuti kompartemen model orde pertama dengan waktu paruh 30,61 menit dan volume distribusi $7760,50 \mathrm{~mL}$. Siklus enterohepatika mengakibatkan perpanjangan waktu paruh.
\end{abstract}

Kata kunci: kodein; farmakokinetik; kelinci; TLC-spektrofotodensitometri

\begin{abstract}
The codeine has been used as a marker for illicit heroin uses, that for to increasing differentiating illicit heroin uses, it needs the codeine pharmacokinetic data. Eleven rabbit have been injected 11.04 mg codeine (with body weight: $\pm 1.8 \mathrm{~kg}$ ) via marginal vena. Blood have taken at every $5,15,30,60$, 90 , and 120 minutes. Serum has stored at $-20{ }^{\circ} \mathrm{C}$ before analyzed. Blood protein was predicated by isoprophanol. Codeine was extracted with chloroform-isopropanol $(3: 1)$ and buffer phosphate $0.2 \mathrm{~N} \mathrm{pH}$ 9.3 then separated by phase toluene-acetone-ethanol-ammonia (45:45:7:3) as mobile phase and aluminum sheet of silica thin layer chromatography Gel $60 \mathrm{~F}_{254}$ as stationary phase. Codeine determined by spectrophotodensitometry at $215 \mathrm{~nm}$. Limit of detection and limit of quantification of codeine was $184.43 \mathrm{ng}$ and $563.62 \mathrm{ng}$ per spot, respectively the percentage recovery of in vitro was $60.60 \%$. Profile concentration of codeine after IV bolus showed decreasing concentration at first terminal and increasing codeine concentration at last terminal that indicated an enterohepatic cycle. Codeine pharmacokinetic followed first compartment with the half time was 30.61 minutes and the distribution volume were $7760.50 \mathrm{~mL}$. Enterohepatic cycle caused prolonged lifetime of codeine at rabbit.
\end{abstract}

Keywords: codeine; pharmacokinetic; rabbit; TLC-spectrophotodensitometry

\section{PENDAHULUAN}

Kodein adalah narkotika golongan ketiga. Kodein hanya dapat digunakan untuk keperluan pengobatan. Kodein sering ditemukan sebagai pengotor dalam heroin ilegal. "Heroin-ilegal" adalah hasil sintesa dari opium. Opium mengandung sekitar (8$17 \%)$ morfin, $(0,7-5 \%)$ kodein, dan alkaloid opiat lainnya (Schiff, 2002). Kodein akan terasetilasi membentuk asetilkodein. Jika seseorang mengkonsumsi heroin ilegal, maka di dalam tubuh akan ditemukan metabolit dari heroin dan asetilkodein. Asetilkodein di dalam tubuh terhidrolisis menjadi kodein. Kodein kemudian mengalami glukoronidasi membentuk 
kodein 6 glukoronid, dan sekitar 10\% akan mengalami O-demetilasi membentuk morfin (Nagy et al., 1999).

Wirasuta (2005), memanfaatkan rasio [kodein]/[morfin] dalam membedakan pengguna heroin ilegal dengan kodein. Ketepatan pemanfaatan rasio [kodein]/[morfin] ditentukan oleh laju eliminasi kodein dan morfin di dalam tubuh. Ratio di atas ditentukan oleh waktu paruh morfin dan kodein. Sehingga pengetahuan akan waktu paruh eliminasi kodein itu sendiri bermanfaat dalam penggunaan rasio [kodein]/[morfin] pada pembedaan pengguna heroin ilegal dengan kodein. Adanya masalah etik untuk melakukan penelitian tentang farmakokinetika pada manusia, mengarahkan penelitian studi farmakokinetika kodein menggunakan kelinci sebagai hewan percobaan. Metode yang digunakan untuk mengidentifikasi sekaligus menetapkan kodein di dalam sampel biologis sedapatnya bersifat cepat, akurat, dan tentu saja murah. Kromatografi lapis tipis yang dipadukan dengan spektrodensitometri (KLTspektrodensitometri) merupakan salah satu alternatif yang dapat digunakan untuk analisis kodein pada sampel biologis.

Tujuan dibuatnya penelitian ini adalah untuk mengetahui farmakokinetika dari kodein dalam tubuh kelinci setelah pemberian kodein secara intravena serta mengetahui pemanfaatan teknik analisis TLC-spektrofotodensitometri dalam analisis kodein dalam darah kelinci. Hasil yang diperoleh kemudian dapat diekstrapolasikan ke manusia sehingga dapat digunakan untuk menentukan laju eliminasi kodein dalam tubuh, serta kedepannya dapat bermanfaat dalam penentuan waktu pemakaian heroin dan jenis narkotika yang digunakan guna kepentingan bidang toksikologi forensik.

\section{METODE PENELITIAN}

\section{Materi penelitian}

Kodein fosfat, diperoleh dari Kimia Farma dan standard baku pembandingnya diperoleh dari PPOM-BPOM RI di Jakarta. Bahan-bahan kimia yang digunakan terdiri dari metanol, kloroform, isopropanol, toluene, aseton, etanol, ammonia pekat yang kesemuanya derajat pro analisis (MERCK). Plat Al-TLC si 60 GF 254 dan pelat HPTLC si 60 GF 254 (MERCK) ukuran 10x10 cm.

Peralatan yang digunakan dalam penelitian ini meliputi alat-alat gelas, timbangan analitik (AND GR-200), micro syringe $100 \mu \mathrm{L}$ (Camag), Linomat 5 (Camag-131210), pH meter (Hanna), TLC Scanner 3 (Camag-Muttenz-Zweitzerland), Sentrifuga (Clements), oven (memmert), ultrasonik (Quigg) dan shaker (IKA).

\section{Pembuatan larutan injeksi kodein}

Kodein ditimbang dengan seksama sebanyak 0,0110 gr di dalam vial, kemudian disterilkan pada oven dengan suhu $110^{\circ} \mathrm{C}$ selama 30 menit. Vial rekonstruksi dengan air aqua steril sebanyak $0,5 \mathrm{~mL}$ dan kocok hingga semua kodein terlarut

\section{Analisis kodein dalam darah}

Sebanyak 11 kelinci galur lokal disiapkan. Sebelum penyuntikan kodein, dilakukan pengambilan sampel t0. Sampel darah kelinci diambil sebanyak 8 kali yaitu pada waktu 5, 15, 30,t60, 90, dan 120, menit setelah injeksi. Sampel darah diambil sebanyak 0,5 $\mathrm{mL}$ menggunakan syringe, yang telah diberikan heparin, dari vena pembuluh darah telinga kelinci. Sampel darah dimasukkan ke dalam eppendorf 1,5 $\mathrm{mL}$ lalu disimpan pada suhu minus $20{ }^{\circ} \mathrm{C}$.

Masing-masing sampel ditambah $1 \mathrm{~mL}$ isopropanol, kemudian disentrifugasi dengan pada $8000 \mathrm{rpm}$ selama 5 menit. Sebanyak $0,5 \mathrm{~mL}$ sepernatan dipindahkan ke dalam tabung sentrifuga, kemudian ditambahkan 0,5 $\mathrm{mL}$ buffer fosfat dengan $\mathrm{pH}$ 9,3 dan $3 \mathrm{~mL}$ campuran pelarut isopropanol dan kloroform (1:3). Masingmasing tabung dikocok dengan pengaduk mekanik dengan kecepatan $3000 \mathrm{rpm}$ selama 15 menit hingga terbentuk emulsi, kemudian disentrifugasi pada kecepatan $3500 \mathrm{rpm}$ selama 15 menit. Lapisan 
kloroform dipisahkan dan dipidahkan ke dalam tabung yang baru, dan diuapkan menggunakan penangas air. Ekstrak kering direkonstruksi menggunakan $25 \mu \mathrm{L}$ metanol lalu di ultrasonik untuk melarutkan. Semua ekstrak ditotolkan pada plat.

Larutan standar kodein dengan konsentrasi $50 \mathrm{ng} / \mu \mathrm{L}$. Larutan standard ditotolkan pada plat mengunakan Linomat 5 pada volume $2 \mu \mathrm{L}, 5 \mu \mathrm{L}, 10 \mu \mathrm{L}$, dan 25 $\mu \mathrm{L}$ sehingga diperoleh jumlah penotolan sebanyak 100, 250, 500, dan $1250 \mathrm{ng}$ kodein fosfat.

Penotolan dilakukan pada jarak $10 \mathrm{~mm}$ dari tepi kiri dan bawah plat. Plat dielusi menggunakan sistem pengembangan toluen:aseton:etanol: amonia P (45:45:7:3 v/v). Pejenuhan chember dilakukan selama 30 menit, kemudian plat dielusi sampai 90 $\mathrm{mm}$ dari tepi bawah. Plat kemudian dikeringkan dalam oven pada suhu $60{ }^{\circ} \mathrm{C}$ selama 5 menit.

Kromatogram dibaca dibawah TLCScanner 3, dengan sistem reflaktan pada celah sinar datang $6 \times 0,3 \mathrm{~mm}$, panjang gelombang $\lambda_{\max } 212 \mathrm{~nm}$, masing-masing puncak kromatogram dirajah spektrum UV insitu pada rentang panjanggelombang (190 $\mathrm{s} / \mathrm{d} 400 \mathrm{~nm}$ ).

Validasi

Validasi metode meliputi penetapan presisi, akurasi, batas deteksi, batas kuantifikasi, rentang linearitas, dan perolehan kembali. Uji validasi mengacu pada metode ICH 2004.

Perhitungan parameter farmakokinetik kodein

Kadar kodein dalam darah persatuan waktu ditetapkan parameter farmakokinetiknya menggunakan metode kompartemen model. Waktu paruh, tetapan laju eliminasi dan volume distribusi (Vd) sesuai dengan persamaan dari kompartemen yang digunakan.

\section{HASIL DAN PEMBAHASAN}

Presisi penetapan kadar kodein ditampilkan pada Tabel 1, sedangkan Tabel 2 menggambarkan nilai batas kuantitasi
(LOQ) dan batas deteksi (LOD) pengukuran. Perolehan kembali penetapan kadar kodein di dalam plasma ditampilkan dalam Tabel 3. Validasi metode penetapan kadar kodein memenuhi kriteria dan dapat digunakan dalam perhitungan farmakinetika kodein pada kelinci.

Tabel 1 Presisi penetapan kadar kodein dengan Spektrofotodensitometri $(n=6)$

\begin{tabular}{|c|c|c|}
\hline ng/spot & Rataan & $\mathrm{KV}$ \\
\hline 78,1 & 799.5 & 9.4 \\
\hline 195,3 & 1756.2 & 10.6 \\
\hline 976,3 & 6701.1 & 9.1 \\
\hline
\end{tabular}

Tabel 2. Nilai batas deteksi dan ban batas kuantitasi

\begin{tabular}{lrrr}
\hline Plat & LOD (ng) & LOQ (ng) & Linieritas \\
\hline 1 & 118,77 & 395,91 & 0,99 \\
2 & 121,53 & 98,13 & 0,99 \\
3 & 294,66 & 982,21 & 0,99 \\
4 & 72,08 & 240,27 & 0,99 \\
5 & 220,58 & 735,29 & 0,99 \\
6 & 278,97 & 929,91 & 0,99 \\
\hline Rataan & 184,43 & 563,62 & 0,99 \\
\hline
\end{tabular}

Profil konsentrasi kodein pada kelinci setelah pemberian kodein secara intravena pada Gambar 1, memperlihatkan bentuk profil dari tiap kelinci berbeda-beda terutama pada menit awal (menit ke 5-60). Profil kelinci 1, 2, 3, 8, 10 dan 11 menunjukkan penurunan konsentrasi kodein dalam darah tiap satuan waktu. Namun sedikit berbeda pada profil kodein kelinci 4, 5, 6, 7, dan 9, dimana pada menit awal $(\mathrm{t}=5)$ terjadi peningkatan konsentrasi kodein sebelum akhirnya konsentrasi kodein menurun sampai menit ke 60 . Pemberian obat secara injeksi intravena cepat (iv bolus) mengakibatkan seluruh obat masuk dalam tubuh dengan segera. Distribusi obat keseluruh jaringan ditandai dengan adanya penurunan konsentrasi obat dalam darah tiap satuan waktu. Perbedaan profil ini dapat disebabkan oleh banyak faktor. Optimalnya proses ekstraksi sangat berpengaruh pada titik-titik kadar tiap waktu dari profil kodein tiap kelinci. Tabel 2 menampilkan rentang persentase 
perolehan kembali ekstraksi kodein dalam darah kelinci secara in vitro yang cukup luas. Hal ini mendasari berbedanya bentuk profil pada beberapa kelinci sehingga perlu adanya evaluasi ulang pada proses ekstrasi.

Tabel 3. Perolehan kembali ekstraksi kodein dalam darah kelinci secara in vitro dengan dapar fosfat

\begin{tabular}{|c|c|c|c|}
\hline & $\begin{array}{l}\text { Kadar } \\
\text { (ng) }\end{array}$ & $\begin{array}{l}\text { Hasil } \\
\text { ekstraksi(ng) }\end{array}$ & $\begin{array}{l}\text { \% } \\
\text { perolehan } \\
\text { kembali }\end{array}$ \\
\hline 1 & 520,7 & 340,83 & 65,5 \\
\hline 2 & 208,3 & 155,72 & 74,8 \\
\hline 3 & 520,7 & 216,06 & 41,5 \\
\hline \multicolumn{3}{|c|}{ Standar Deviasi } & 17,2 \\
\hline \multicolumn{3}{|c|}{ Rata-rata } & 60,6 \\
\hline \multicolumn{3}{|c|}{ Koefisien variansi $(\%)$} & 28,3 \\
\hline
\end{tabular}

Pada kelinci 2, 3, 4, 5 dan 6 diamati peningkatan Profil kodein pada menit terakhir (>120 menit) menunjukkan bentuk profil yang sama pada seluruh kelinci dimana terjadi peningkatan kadar kembali dari kodein. Hal ini tampak pada gambar 1, dari profil kelinci 2 sampai 6. Namun pada kelinci lainnya peningkatan kadar kembali ini tidak dapat diamati karena sulitnya memperoleh data pada menit terakhir. Hal ini disebabkan karena adanya siklus enterohepatik yaitu reauptakenya kodein kembali ke dalam sirkulasi darah sehingga memperpanjang waktu tinggal morfin di dalam tubuh. Suatu senyawa yang diekskresikan ke dalam empedu dan memasuki intestinum dapat mengalami ekskresi melalui feses, namun mikroflora usus yang terdapat diintestinum dapat menghidrolisis berbagai metabolit glukoronid sehingga memungkinkan senyawa tersebut diserap kembali dan masuk kedalam sirkulasi dalam dalam bentuk utuhnya (Texier et al., 1998). Kodein mengalami glukuronidasi dihati menjadi kodein-6-glukuronida lalu diekskresikan ke dalam usus halus, dan oleh enzim $\beta$-gukuronidase yang dihasilkan oleh flora normal usus bentuk glukuronida kodein dihidrolisis menjadi bentuk kodein kembali (Rowland and Tozer, 1995).

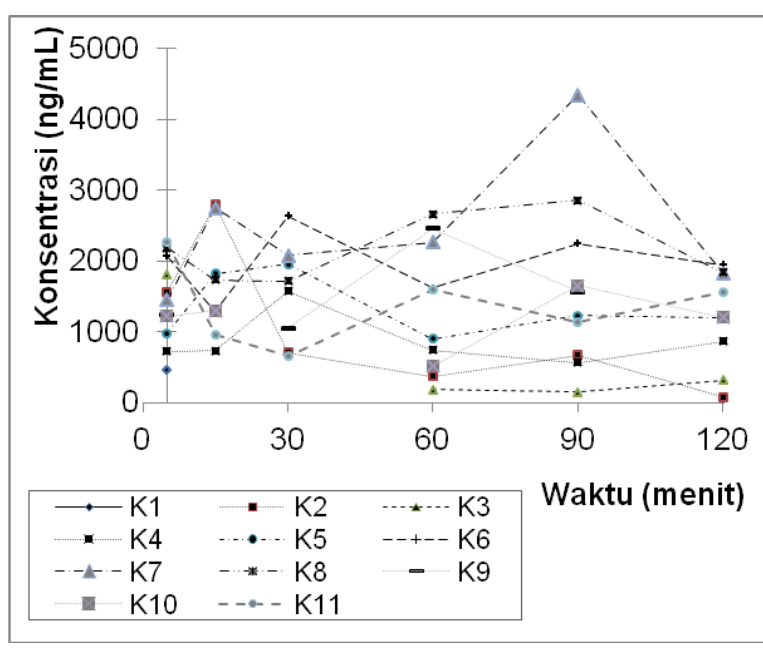

Gambar 1. Profil konsentrasi kodein pada kelinci setelah pemberian IV

Penetapan

kompartemen

farmakokinetik dapat dilakukan dengan melihat profil konsentrasi dari tiap-tiap kelinci pada Gambar 1. Pada Gambar 2 ditampilkan plot antara log konsentrasi kodein dengan waktu dari tiap-tiap kelinci.

Penentuan model kompatemen ini diperoleh dengan memplot logaritma konsentrasi kodein dengan waktu. Namun, dari semua uji menunjukkan adanya siklus enterohepatik pada akhir terminal yaitu pada menit di atas 120 menit seperti pada gambar 1. Sehingga untuk menentukan kompartemen farmakokinetik hanya digunakan data kadar dalam darah pada waktu di bawah 120 menit, karena sampai saat ini kompartemen untuk adanya siklus enterohepatik belum ada serta sulitnya menetapkan model yang tepat. Profil konsentrasi yang dihasilkan menunjukkan adanya laju penurunan konsentrasi obat secara konstan mengikuti model kompartemen satu.

Parameter farmakokinetik dihitung dengan persamaan dan perhitungan dari model kompartemen satu. Nilai tetapan farmakokinetik (k) diperoleh dari plot antara logaritma konsentrasi kodein dengan waktu dimana daerah penyebaran data membentuk garis linier. Persamaan garis linier yang diperoleh memiliki nilai aras kepercayaan $10 \%$ sehingga membatasi nilai linieritas (r) lebih besar sama dengan 0,90 $(\geq 0,90)$. 

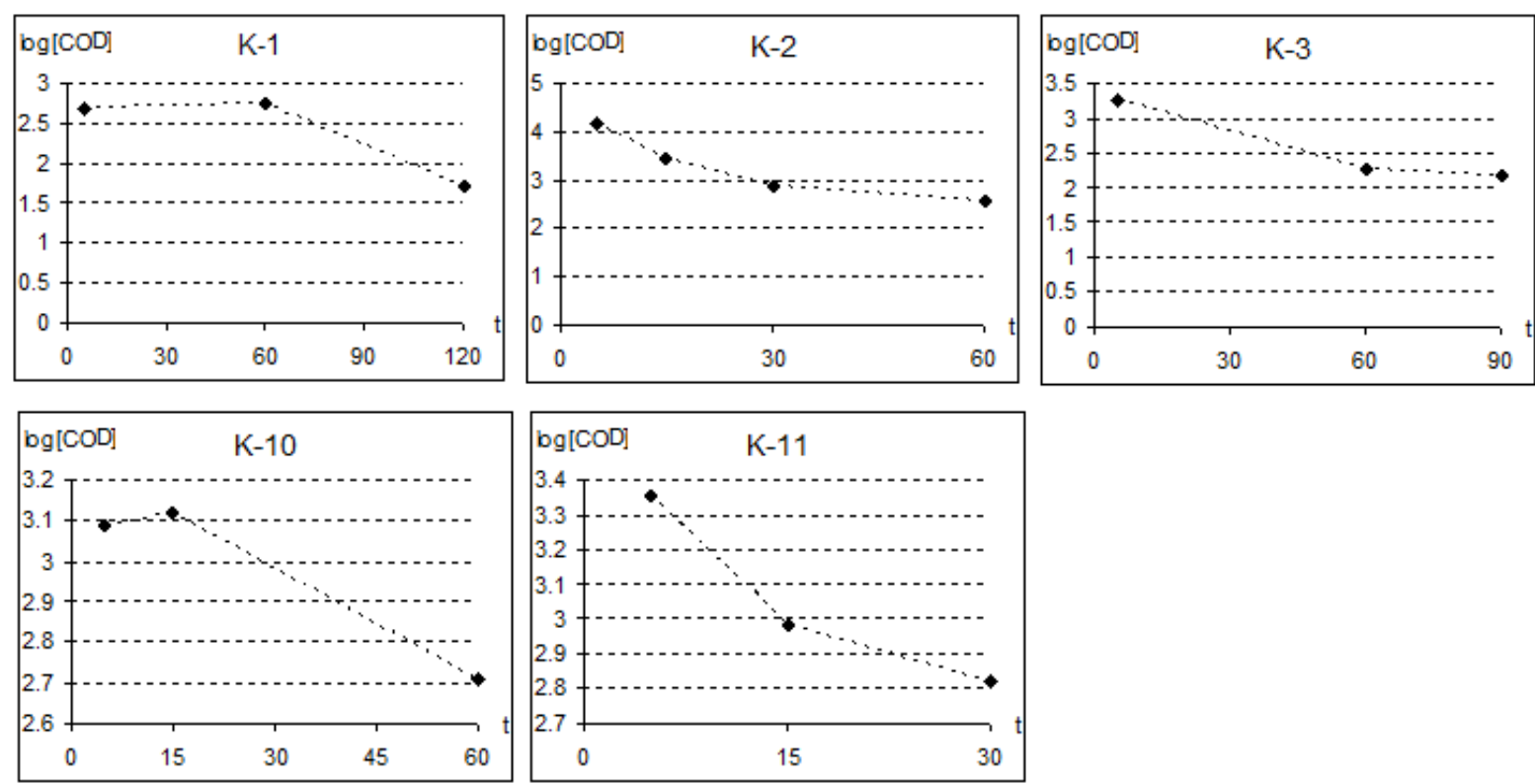

Gambar 2. Kurva log konsentrasi kodein terhadap waktu

Keterangan: $\mathrm{K}-\mathrm{n}=$ kelinci ke- $\mathrm{n},[\mathrm{COD}]=$ konsentrasi kodein, $\mathrm{t}=$ waktu (menit)

Tetapan laju reaksi farmakokinetik yang dinyatakan dalam satuan waktu ${ }^{-1}$ (menit ${ }^{-1}$ ) digunakan dalam menentukan nilai waktu paruh. Nilai parameter farmakokinetik berupa nilai tetapan farmaskokinetik (k) dan waktu paruh ditampilkan pada Tabel 4.

Tabel 4. Nilai Parameter farmakokinetik dan waktu paruh

\begin{tabular}{ccl}
\hline Kelinci & $\mathrm{K}\left(\right.$ menit $\left.^{-1}\right)$ & $\mathrm{t}_{1 / 2}$ (menit) \\
\hline 1 & 0,0133 & 52,11 \\
2 & 0,0300 & 23,10 \\
3 & 0,0309 & 22,43 \\
4 & 0,0171 & 40,76 \\
5 & 0,0473 & 14,65 \\
\hline & Rata-rata & 30,61 \\
\hline
\end{tabular}

Keterangan: $\mathrm{k}=$ tetapan farmakokinetik; $\mathrm{t} 1 / 2=$ waktu paruh

Tabel 5. Nilai volume distribusi

\begin{tabular}{|c|c|c|}
\hline Kelinci & $\mathrm{Cp}^{0}(\mathrm{ng} / \mathrm{ml})$ & $\mathrm{Vd}(\mathrm{ml})$ \\
\hline 1 & 399,15 & 21600,90 \\
\hline 2 & 2704 & 3188,61 \\
\hline 3 & 1818 & 4742,57 \\
\hline 4 & 1486,7 & 5799,42 \\
\hline 5 & 2484 & 3471,01 \\
\hline \multicolumn{2}{|r|}{ Rata-rata } & 7760,50 \\
\hline
\end{tabular}

Keterangan : $\mathrm{Cp} 0=$ konsentrasi plasma pada $\mathrm{t}=0 ; \mathrm{Vd}=$ volume distribusi
Nilai $\mathrm{Cp}^{0}$ digunakan dalam menentukan nilai volume distribusi. Nilai volume distribusi (Vd) dapat dihitung dari persamaan (12), dan ditampilkan seperti pada Tabel 5

\section{SIMPULAN}

Profil farmakokinetika kodein mengikuti model kompartemen satu. Nilai parameter kodein berupa waktu paruh (t1/2) dan Volume distribusi (Vd) berturutturut sebesar 30,61 menit dan 7760,50 ml. Teknik analisis TLCspektrofotodensitometri dapat digunakan untuk menganalisis kodein dalam darah kelinci.

\section{SARAN}

Saran dilakukan studi intraindividual pemberian morfin dan kodein bersamaan.

\section{UCAPAN TERIMAKASIH}

Terimakasih penulis ucapkan kepada semua pihak yang telah membantu kelancaran penelitian ini.

\section{DAFTAR PUSTAKA}

Nagy AD, Rivier L, Giroud C, Augsburger M, Mangin P. 1999. Method for quantification of morphine and its 3- 
and 6-glucuronides, codeine, codeine glucuronide and 6monoacetylmorphine in human blood by liquid chromatography electrospray mass spectrometry for routine analysis in forensic toxicology. $J$. Chromatograph. 854: 109-118.

Rowland M, Tozer TN. 1995. Clinical pharmacokinetics concepts and application. $3^{\text {rd }}$ Ed. Lippincott Williams \& Wilkuns. Philadelphia.

Schiff P. 2002. Opium and its alkaloids. Am. J. Pharmaceutic Edu. 66: 186-194. Shargel L, Yu A. 1999. Biopharmacetics and pharmacokinetic. $4^{\text {th }}$ Ed. United State. Prentice-Hall International Inc.

Texier JP, Bertran P, Coutard JP, Francou B, Gabert P, Guadelli JL,Ozouf JC,
Plisson H, Raynal JP, Vivent D. 1998. Transit, an experimental archaeological program in periglacial environment: problem, methodology, first results. Int. J. Geoarchaeol. 143(5): 433-473.

Wirasuta IMAG. 2005. Hambatan dalam penegakan Undang-Undang No. $22 \mathrm{Th}$ 1997 tentang narkotika, khususnya pada penyalahgunaan narkotika golongan opiat ditinjau dari sifat farmakokinetiknya. Dalam: Wirasuta I MAG, Yowani SC, Suaniti NM, Wirajana N, Junitha K, Alit IB, I.B.P., Leliqia, E., Ariantari. Peranan Kedokteran Forensik Dalam Penegakan Hukum Di Indonesia. Bali: Universitas Udayana, Pp: 127-132. 